\title{
ANALYZING THE ATTITUDES OF MANAGERS ON THE REPRESENTATION OF HOTEL TOURISM IN THE CONDITIONS OF THE MODERN GLOBALIZATION PROCESS
}

\author{
Samira Dedić \\ University of Tuzla, Faculty of Economics \\ Univerzitetska 8, 75000 Tuzla, BiH \\ samira.dedic@untz.ba \\ Amra Nuhanović \\ University of Tuzla, Faculty of Economics \\ Univerzitetska 8, 75000 Tuzla, $\mathrm{BiH}$ \\ amra.nuhanovic@untz.ba \\ Jasenka Đulić \\ Rudnička b.b., 75300 Lukavac, BiH \\ jasenka.djulic@hotmail.com
}

\begin{abstract}
Globalization processes are increasingly affecting segments of the tourism market, where the hotel industry is particularly prominent. The functioning of the tourist market in the conditions of globalization requires the construction of an international business infrastructure, which is represented by numerous international institutions and agreements. Properly formed international infrastructure provides a favourable climate for globalization, overall control and insight into the economic, financial and political aspects of business. The development of tourism and hotel management in Bosnia and Herzegovina is still in its infancy, but progress still exists. With this in mind, the authors presented the results of research and examination of the attitudes of managers on the importance of tourist satisfaction, implementation of various hotel services and performance indicators of hotel companies in $\mathrm{BiH}$. The authors came to the conclusion that hoteliers in $\mathrm{BiH}$ have taken the path of quality, but, however, they do not do it systematically yet. It is notorious that Bosnian hoteliers have great prospects, but first and foremost they have to solve many problems and weaknesses, in order to improve all the performance of business excellence. By using self-assessment of the business excellence of one's own company based on its performance, one can come to very good indicators of the situation, as well as conclusions about the areas of business that need to be improved
\end{abstract}

Ključne riječi: globalization, managers, hotel tourism, stratified sample, descriptive statistical analysis.

\section{ANALIZIRANJE STAVOVA MENADŽERA O ZASTUPLJENOSTI HOTELSKOG TURIZMA U USLOVIMA SAVREMENOG PROCESA GLOBALIZACIJE}

\author{
Apstrakt \\ Globalizacijski procesi sve više zahvataju i segmente turističkog tržišta, gdje se posebno ističe \\ hotelijerstvo. Funkcionisanje turističkog tržišta u uslovima globalizacije zahtijeva izgrađenost
}


međunarodne poslovne infrastrukture, koju predstavljaju brojne međunarodne institucije i sporazumi. Pravilno formirana međunarodna infrastruktura osigurava povoljnu klimu za globalizaciju, sveukupnom kontrolom i uviđanjem ekonomskog, finansijskog i političkog aspekta poslovanja. Razvoj turizma odnosno hotelijerstva u Bosni i Hercegovini tek je u početnoj fazi ali napredak ipak postoji. Imajući to u vidu, autorice su u radu prezentirale rezultate istraživanja I ispitivanja stavova menadžera o važnosti zadovoljstva turista, implementiranja različitih hotelskih usluga i pokazatelja uspješnosti hotelskih preduzeća u $\mathrm{BiH}$. Autorice su došle do zaključka da su hotelijeri u BiH krenuli putem kvaliteta, ali međutim, to još ne čine sistemski. Notorno je, da bosanskohercegovački hotelijeri imaju veliku perspektivu, ali prvenstveno moraju riješiti brojne probleme i slabosti, kako bi unaprijedili sve performanse poslovne izvrsnosti. Korištenjem samoprocjene poslovne izvrsnosti vlastitog poduzeća na temelju njenih performansi, može doći do vrlo dobrih pokazatelja stanja, kao i zaključaka o područjima poslovanja koje je potrebno unaprijediti

Key words: globalizacija, menadžeri, hotelski turizam, stratifikovani uzorak, deskriptivna statisticka analiza.

JEL codes: F66, C19, A12

\section{INTRODUCTION}

Globalization has brought consolidation for the hotel industry, i.e. merging and merging smaller hotels into larger hotel chains. The internationalization of business leads to business connections between bidders, in order to improve business efficiency and achieve the highest possible profit. All integrated holders of the tourist offer strive to satisfy the tourist demand to the maximum, in order to make a possible profit from this form of business. The purpose of integration is to create a whole in which a certain degree of coordination is established among numerous entities, which participate in the provision of complex tourist services.

In the hotel industry, globalization is most pronounced in the efforts of hotel companies to apply international business standards and to obtain the status of a global economic entity. International hotel chains, i.e. their origin and development, represent the initial capsule, ie the driving motive, which paved the way for the expansion and globalization of the hotel industry across the planet. In a very short time, hotel chains have become synonymous with the hotel industry and have also contributed to its opening and popularization. Thanks to its growth and development and increasing territorial distribution in every part of the planet, hotel chains have directly influenced the diversification of the most modern industry and it is estimated that in the very near future it will become one of the most profitable activities.

In recent years, there has been an expansion of the importance of the service sector in international trade, among which hotel tourism occupies a prominent place. Tourism today is one of the most profitable and largest industries in the world, with predictions that the global economic and social climate, despite uncertain opportunities in parts of the world and the global economic crisis, will result in an increase in tourism in the next twenty years. It is believed that because of this, tourism will become the largest industry and the most important export sector in the world. (http://web.efzg.hr/dok/TUR/avlahov/01_3A_struktura\%20hotelske\%20industrije.p df). 
Analyzing the attitudes of managers on the representation of hotel tourism in the conditions of the modern globalization process

Hotel tourism has an explicit impact on macroeconomic aggregates and increases the macroeconomic stability of each country. In this way, it affects almost all branches of the national economy and as such creates multipliers of GDP growth, employment and investment, enables acceleration of regional and local development, starts production to meet tourism needs, enhances foreign exchange inflows and improves the country's balance of payments. increase in overall employment. [Arnaut, Fehrić, (2011), p. 8] A special development aspect of tourism is reflected in the external effects that tourism has on a number of activities in the economy and society, starting from food and beverage production, road, rail and air transport, infrastructure development and investment in destination facilities, through hotel development, trade and the entertainment industry to launch the development of a range of financial, marketing and educational services and changes in the country's rural, environmental and spatial development, and to raise the well-being and living standards of countries that promote and support tourism development.

Despite the fact that $\mathrm{BiH}$ has a large number of natural beauties, lack of accommodation capacity and quality road infrastructure, are an obstacle to the development of $\mathrm{BiH}$ tourism. Although it has huge potential, the development of tourism in $\mathrm{BiH}$ is only in its infancy. According to estimates given in the Global Tourism Competitiveness Report for 2010, it is estimated that the tourism industry (narrower access to tourism with direct effects in the hospitality, hotels and other industries) achieves 461 mil. dollars of GDP, ie to participate in the GDP of BiH with $2.9 \%$, and to employ 26,000 workers and participate in the total employment with $2.3 \%$, but the tourism industry, ie banking, trade, etc. create greater value in BiH GDP (http://unvi.edu.ba/Files/zbornici/turizam_u_funkciji_lokalnog_razvoja.pdf)

To achieve sustainable, long-term growth, hoteliers must develop a deep understanding of the type of customers they want to attract and then offer an experience tailored to a specific group of guests. Education of management and other employees is an important element in providing quality products, and at the same time an element on which progress is gradually being made in $\mathrm{BiH}$ (http://unvi.edu.ba/Files/zbornici/turizam_u_funkciji_lokalnog_razvoja.pdf)

Trends and technology in the hotel industry are changing very quickly. Taking into account this fact, it is necessary to constantly educate employees, which of course requires the allocation of appropriate financial resources. Namely, in most hotels in $\mathrm{BiH}$, the sector holders do not have the necessary knowledge and experience. The importance of education of management and other employees is shown by the data from 2011, where the idea of cooperation with the then largest foreign investor in Bosnia and Herzegovina Al Shiddi Group and the University of Sarajevo, and the signing of the Agreement, which actually referred to education as well as training of employees from Bosnia and Herzegovina and abroad. The agreement envisages the organization of various educational workshops, seminars, in essence the exchange of knowledge, although with education as the main goal, but also a motive to awaken interest in young people for the hotel industry in Bosnia and Herzegovina, and modern tourism in general.

As already mentioned, the development of tourism and hotel management in Bosnia and Herzegovina is still in its infancy, but progress still exists. This is proved by the fact that for two years in a row, the Bristol Hotel in Sarajevo has received a certificate 
of excellence awarded by the tourist portal TripAdvisor. Namely, it is a recognition that pays respect for the provision of services, and is awarded to those hotel and similar facilities for the accommodation of guests, which achieve excellent reviews of travelers through TripAdvisor. TripAdvisor is an American website that provides travel-related opinions and content. Hotel Bristol in Sarajevo is the first, but also the only international hotel in Bosnia and Herzegovina, and it is managed by the international hotel group "Shaza Hotels". Shaza Hotels is an independent five-star hotel operator, supported by prestigious partners including the Kempinski hotel chain. It is a member of the "Global Hotel Alliance", which brings together 14 highly positioned and luxury regional hotel brands around the world. http://www.ekapija.com/website/bih/page/738644/Hotel-Bristol-u-Sarajevu-dobiocertifikat-izvrsnosti-turisti\%C4\%8Dkog-portala-TripAdvisor).

\section{PREVIOUS RESEARCH}

In the literature, we find a large number of papers and research on the attitudes of international managers on the importance of tourist satisfaction, the implementation of various hotel services and indicators of success of hotel companies. The paper used the results of several researches as a basis for defining the research problem, on the basis of which the systematization of theoretical concepts and the results of previous researches was made.

One of the most important authors in this area, which deals with the topic of business excellence and its impact on all aspects of the hotel business, is Ivana Žilić. In his paper "Business Excellence in Highly Categorized Hotels in Croatia", he tries to determine and define the choice of key dimensions of business excellence, explore the attitude of strategic hotel management in Croatia, and determine the impact of strategic dimensions of business excellence on guest satisfaction and hotel product / service. By analyzing the results, a high degree of importance and need for strategic dimensions of business excellence in the hotel industry was determined, as well as the impact of a set of dimensions of business excellence on hotel guest satisfaction and hotel offer.

In the paper entitled "The impact of employee satisfaction on the quality of products and services in the hotel company", the authors Vrtiprah and Sladoljev (2012) point out that the hotel company, as the primary carrier of the tourist offer, should primarily have professional and satisfied employees. extremely sensitive to the lack of quality in every respect, and insufficiently professional and dissatisfied employees can negatively affect the satisfaction of guests, and thus the competitiveness and business success of the hotel. The aim of this paper is to investigate the interdependence of employee job satisfaction and guest satisfaction with the quality of products and services provided in the hotel company. According to the authors, a hotel company must be guided by the idea that investing in the quality of products and services, and investing in employees, ie. in their education and motivation, represents a cost, which ultimately brings greater guest satisfaction and greater financial results. Therefore, managers must continuously have information on the job satisfaction of providers of 
Analyzing the attitudes of managers on the representation of hotel tourism in the conditions of the modern globalization process

hotel products and services and on guest satisfaction with the quality of products and services provided.

The author of the paper "Quality as the basis of market success of a hotel company", Krunoslav Čačić, states the fact that the quality of service is inseparably correlated with the standards, ie with the operationally defined standards in the hotel. Standards in the creation and provision of hotel services are necessary primarily to ensure the quality of services and continuous, effective business.

In his paper, which refers to determining the relationship between service quality and customer satisfaction, Sekulović (2009) points out that only by providing continuous and complete service quality, preconditions are set for achieving consumer satisfaction (service users), and in that sense by providing the desired quality. for consumers and their satisfaction achieve a number of competitive advantages.

The professional paper "The quality of hotel service is a reflection of organizational culture", Perkov (2005), emphasizes that the corporate or organizational culture of the so-called. an "intangible" factor of business success. It implies common values, rules of conduct, symbols and experiences that connect employees and reflect the identity of the company. Managers must lead their organization in the space and time of their cultural environment, respecting the trends and criteria of the process of regionalization, internationalization and globalization.

In his doctoral dissertation entitled "Brand Strategy in the Function of Market Positioning of Hotel Chains," Svorcan (2011) explains the impact of globalization on the hotel industry. He cites the development of international trade or export marketing, the creation of strategic alliances, and foreign direct investment as the main drivers of globalization. In the hotel industry, for the basic carriers of modern globalization, it emphasizes transnational (TNK) and multinational (MNK) companies. They achieve the process of globalization with the help of appropriate organization, technology, money and ideology. In addition, the paper lists certain barriers in the hotel industry such as culture, language, legal regulations, then political stability, climate, racial barriers, etc. Therefore, he concludes, that only by standardizing the entire business of hotel companies, they can overcome or at least reduce.

The growth of competition in the hotel industry has a great impact on consumers by providing them with a variety of choices, greater value for money and a higher level of service. The authors of the paper "Quality of services as a determinant of consumer satisfaction in tourism", Sekulić and Mandarinić (2013) try to point out the importance of the quality of services on consumer satisfaction in hotel companies. The results of the research conducted in this paper identify the most important factors that drive consumer satisfaction. As the most significant factor, the price is marked. In addition, the services of hotel staff and the quality of hotel accommodation have been identified as extremely important factors in consumer satisfaction.

The paper entitled "Manager and management process in the hotel industry - a modern approach" deals with defining and determining the basic specifics of the work of managers in the hotel industry. Nikolic (2002) also states the specifics of the functioning of management in this area, and by determining the basic principles and components of management in hotels and hotel corporations. 


\section{RESEARCH METHODOLOGY}

Empirical research was realized on the basis of primary data collection by field research, using the survey method (written examination technique) using a highly structured survey questionnaire as a form for data collection. Primary data were collected by the management of hotel companies from the territory of $\mathrm{BiH}$. The survey questionnaire referred to questions about the attitudes of respondents towards the degree of implementation of the concept of business excellence and its impact on the success of hotel operations. The basis for structuring the sample was data from the register of the Indirect Taxation Authority of $\mathrm{BiH}$ (ITA), the Association of Hoteliers and Restaurateurs of $\mathrm{BiH}$, and the Federal Ministry of Environment and Tourism. Data collection was performed on the basis of a proportional stratified sample, since it belongs to the category of random samples and allows to assess the degree of reliability of conclusions about the investigated parameters. Since these are hotel companies, the categorization criterion used the categorization of hotel facilities, which is determined by the number of stars in hotels. The choice of hotel categorization as a stratification criterion is based on the results of examinations by experts from the Association of Hoteliers and Restaurateurs of $\mathrm{BiH}$ and the Federal Ministry of Environment and Tourism.

The empirical research was conducted on a sample of hotels of the first and second category, ie it included two strata: four and five star hotels. According to the existing data, the total number of such hotels in $\mathrm{BiH}$ is 95 . Since this is a concept of business excellence, this research does not include hotels of lower categories. Data collection was performed in the period from April to August 2015. The fraction, ie the rate of hotel selection in the sample was $45.26 \%$. Thus, the selected hotels are classified according to the number of stars in two strata. The structure of the sample according to the number of stars is presented in Table 1.

Table 1. Sample size and structure

\begin{tabular}{|c|c|c|c|c|c|c|}
\hline Category & \multirow{2}{*}{$\begin{array}{c}\text { Number } \\
\text { asterisk }\end{array}$} & \multicolumn{2}{|l|}{ The basis of choice } & \multicolumn{3}{|c|}{ Sample } \\
\cline { 3 - 7 } & & $\begin{array}{c}\text { Number of } \\
\text { hotels }\end{array}$ & $\%$ & $\%$ & $\begin{array}{c}\text { Number } \\
\text { of hotels }\end{array}$ & $\begin{array}{c}\text { Number of } \\
\text { hotels in } \\
\text { sample }\end{array}$ \\
\hline 1 & 5 & 10 & 10,53 & 10,53 & 4,53 & 5 \\
\hline 2 & 4 & 85 & 89,47 & 89,47 & 38,47 & 38 \\
\hline$\Sigma$ & 95 & $\begin{array}{c}100,0 \\
0\end{array}$ & $\begin{array}{c}100,0 \\
0\end{array}$ & 43 & 43 \\
\hline \multicolumn{7}{|c|}{ faction of choice: $(43 / 95) * 100=0,4526^{*} 100=45,26 \%$} \\
\hline
\end{tabular}

Source: author's creation

Based on the criteria given in Table 1, the list of hotels is classified into two categories according to the number of stars. A random selection was made for each of the categories individually and thus a list of 43 hotels was formed, ie a list of 5 five-star hotels and a list of 38 four-star hotels. 
Analyzing the attitudes of managers on the representation of hotel tourism in the conditions of the modern globalization process

\section{ANALYSIS AND DISCUSSION OF THE RESULTS OF EMPIRICAL RESEARCH}

In the following, we present and discuss the results of evaluations, ie examinations of managers' attitudes about the importance of tourist satisfaction, implementation of various hotel services and success indicators of hotel companies.

Before analyzing the position of the variable in detail, in Table 2 we will show the familiarity of managers with key concepts related to the concept of business excellence.

Table 2. Familiarity with the concepts related to the concept of business excellence

\begin{tabular}{|c|c|c|c|c|}
\hline \multirow{2}{*}{$\begin{array}{c}\text { Terms related to the concept } \\
\text { of business excellence }\end{array}$} & \multicolumn{2}{|c|}{ Yes } & \multicolumn{2}{c|}{ No } \\
\cline { 2 - 5 } & Absolutely & Relatively & Absolutely & Relatively \\
\hline European Quality Award & 20 & 46,5 & 23 & 53,5 \\
\hline $\begin{array}{c}\text { EFQM business excellence } \\
\text { model }\end{array}$ & 4 & 9,3 & 39 & 90,7 \\
\hline Quality management system & 26 & 60,5 & 17 & 39,5 \\
\hline $\begin{array}{c}\text { Management system } \\
\text { according to ISO standards }\end{array}$ & 32 & 74,4 & 11 & 25,6 \\
\hline TQM & 13 & 30,2 & 30 & 69,8 \\
\hline Self-assessment models & 10 & 23,3 & 33 & 76,7 \\
\hline
\end{tabular}

Source: author's creation

The table shows that most managers are familiar with the management system according to ISO standards $74.4 \%$, followed by the quality management system $60.5 \%$. This is followed by familiarity with the European Quality Award 46.5\%, TQM - total quality management $30.2 \%$, self-assessment models $23.3 \%$ and EFQM business excellence model only $9.3 \%$. The above data are also shown graphically for easier comparison.

Figure 1. Structure of managers familiar with the concepts related to the concept of business excellence

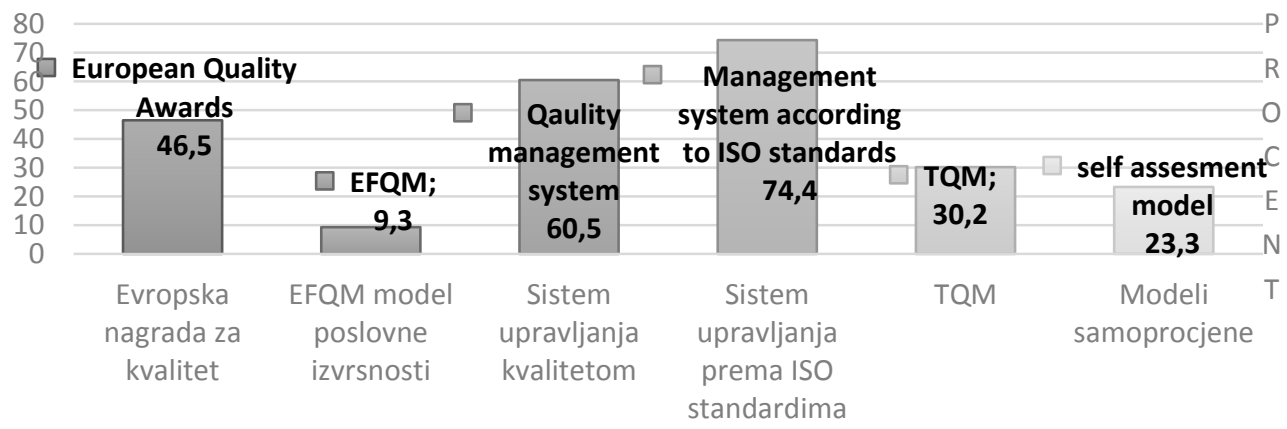

Source: author's creation 
So, we first analyzed the importance of the variable "Tourist satisfaction", which we observed through nine attributes, namely: modern hotel equipment, location and traffic accessibility of the hotel, variety of food and drinks (varied menu), reception at the reception, adequate promotion, friendliness and kindness of the hotel. staff, keeping promises on time, prompt hotel service and security in conducting transactions with staff.

Table 3. Assessing the importance of the variable "Tourist satisfaction"

\begin{tabular}{|c|c|c|c|c|}
\hline Tourist satisfaction & $\begin{array}{c}\text { Arithmetic } \\
\text { mean }\end{array}$ & $\begin{array}{c}\text { Standard } \\
\text { deviation }\end{array}$ & Mod & Median \\
\hline Modern hotel equipment & 4,40 &, 877 & 5 & 5 \\
\hline $\begin{array}{c}\text { Location and traffic } \\
\text { accessibility of the hotel }\end{array}$ & 4,79 &, 559 & 5 & 5 \\
\hline $\begin{array}{c}\text { Variety of food and drinks } \\
\text { (varied menu) } \\
\text { at the reception }\end{array}$ & 4,63 &, 817 & 5 & 5 \\
\hline Reception & 4,86 &, 516 & 5 & 5 \\
\hline $\begin{array}{c}\text { Adequate promotion } \\
\text { The friendliness and kindness } \\
\text { of the hotel staff }\end{array}$ & 4,44 &, 734 & 5 & 5 \\
\hline Making promises on time & 4,93 &, 457 & 5 & 5 \\
\hline Prompt hotel service & 4,86 &, 467 & 5 & 5 \\
\hline $\begin{array}{c}\text { Security in conducting } \\
\text { transactions with hotel staff }\end{array}$ & 4,79 &, 709 & 5 & 5 \\
\hline Source & & & 5 & 5 \\
\hline
\end{tabular}

Source: author's creation

Let us emphasize that the arithmetic means range from 4.40 to 4.93 , which is certainly a sign that the managers have expressed a very strong agreement on the evaluation of the variable "Tourist Satisfaction". As we can see, the hotel managers gave the highest rating to "Friendliness and kindness of the hotel staff" 4.93, followed by three variables with an average rating of 4.86: "Reception at the reception", "Execution of promises on time" and "Prompt hotel service ". Furthermore, the two variables have the same average score of 4.79, namely "Location and transport accessibility of the hotel" and "Security in conducting transactions with hotel staff". If we analyze all the variables that define the satisfaction of tourists, we can conclude that from the aspect of managers, each of them has a very significant importance in the process of improving the hotel business. This is certainly supported by the small values of standard deviations, and the high values of the mode and median.

The next variable that was evaluated by the hotel manager related to the implementation of various hotel services. It is observed through seven attributes: accommodation services, gastronomy, cultural content (local attractions and events), wellness services, facilities for children, sports facilities and congress tourism. The results of descriptive parameters are given in Table 4. 
Analyzing the attitudes of managers on the representation of hotel tourism in the conditions of the modern globalization process

Table 4. Evaluation of the importance of the variable "Implementation of different hotel services"

\begin{tabular}{|c|c|c|c|c|}
\hline $\begin{array}{c}\text { Implementation of different } \\
\text { hotel services }\end{array}$ & $\begin{array}{c}\text { Arithmetic } \\
\text { mean }\end{array}$ & $\begin{array}{c}\text { Standard } \\
\text { deviation }\end{array}$ & Mod & Median \\
\hline Accommodation services & 4,86 &, 516 & 5 & 5 \\
\hline Gastronomy & 4,79 &, 514 & 5 & 5 \\
\hline $\begin{array}{c}\text { Cultural content (local } \\
\text { attractions and events) }\end{array}$ & 4,19 &, 906 & 5 & 4 \\
\hline Wellness services & 4,07 & 1,470 & 5 & 5 \\
\hline Facilities for children & 3,72 & 1,403 & 5 & 4 \\
\hline Sports facilities & 3,72 & 1,386 & 5 & 4 \\
\hline Congress tourism & 4,47 &, 960 & 5 & 5 \\
\hline
\end{tabular}

Source: author's creation

The highest degree of agreement of hotel managers with the proposed claims, when it comes to assessing the importance of the variable "Implementation of various hotel services", is evident in accommodation services, where the average score is 4.86 , then gastronomy 4.79, congress tourism 4.47, cultural facilities (local attractions and events) 4.19 and wellness services 4.07 . The average score below four had the variables contents for children and sports contents 3.72. Therefore, in this sample, the surveyed managers believe that in the process of improving the hotel business, accommodation and gastronomic services are extremely important, which also largely determine the dependent variable implementation of various hotel services.

A descriptive analysis was also performed on the performance indicators of hotel companies, which are observed through three attributes: market position, tourist turnover and hotel profit. The data are presented in Table 5.

Table 5. Evaluation of the importance of the variable "performance indicators of hotel enterprises"

\begin{tabular}{|c|c|c|c|c|}
\hline \multicolumn{1}{|c|}{$\begin{array}{c}\text { Performance indicators of hotel } \\
\text { enterprises }\end{array}$} & $\begin{array}{c}\text { Arithmetic } \\
\text { mean }\end{array}$ & $\begin{array}{c}\text { Standard } \\
\text { deviation }\end{array}$ & Mod & Median \\
\cline { 1 - 3 } Market position & $\begin{array}{l}\text { In order to identify the market profile } \\
\text { and establish the market position of } \\
\text { the hotel, we constantly analyze the } \\
\text { offer and contents of the hotel, we } \\
\text { analyze the favorable opportunities } \\
\text { that exist in the market in the } \\
\text { implementation of the positioning } \\
\text { strategy. }\end{array}$ & 4,28 & 584 & 5 \\
\hline
\end{tabular}




\begin{tabular}{|c|c|c|c|c|}
\hline $\begin{array}{l}\text { The market position of hotel } \\
\text { companies is the result of flexible } \\
\text { adaptation to the requirements of } \\
\text { tourist demand, good coordination of } \\
\text { business activities, constant research } \\
\text { on the service-market relationship, as } \\
\text { well as good organization, vision and } \\
\text { management }\end{array}$ & 4,60 & ,791 & 5 & 5 \\
\hline $\begin{array}{l}\text { With the development of tourism and } \\
\text { its structure, the hotel is increasingly } \\
\text { emphasizing the strategy of } \\
\text { differentiating the "offer package" } \\
\text { according to the relevant market } \\
\text { segments. }\end{array}$ & 4,63 &, 536 & 5 & 5 \\
\hline $\begin{array}{l}\text { Improving the quality of the service } \\
\text { process and monitoring new trends in } \\
\text { the tourism market is a basic } \\
\text { prerequisite for gaining a good } \\
\text { competitive position in the market. }\end{array}$ & 4,63 & ,691 & 5 & 5 \\
\hline $\begin{array}{l}\text { It is characteristic of your hotel to } \\
\text { attach great importance to the overall } \\
\text { understanding and knowledge of all } \\
\text { relevant characteristics of tourists } \\
\text { within the selected segments. }\end{array}$ & 4,47 & ,797 & 5 & 5 \\
\hline Tourist traffic & & & & \\
\hline $\begin{array}{l}\text { Booking a hotel is one of the most } \\
\text { important factors in increasing the } \\
\text { number of arrivals and overnight stays } \\
\text { of domestic and foreign tourists. }\end{array}$ & 4,40 & ,979 & 5 & 5 \\
\hline $\begin{array}{l}\text { Cooperation with travel agencies is } \\
\text { an important factor in the tourist } \\
\text { traffic of hotels }\end{array}$ & 4,67 & ,644 & 5 & 5 \\
\hline $\begin{array}{l}\text { Flexible booking policy is an } \\
\text { important attendance factor. }\end{array}$ & 4,60 & ,791 & 5 & 5 \\
\hline $\begin{array}{l}\text { Online hotel rating (booking.com, } \\
\text { tripadvisor.com) affects the increase } \\
\text { in tourist traffic. }\end{array}$ & 4,35 & 1,066 & 5 & 5 \\
\hline $\begin{array}{l}\text { The Visitors' Club is an effective } \\
\text { instrument for promoting visitor } \\
\text { loyalty and thus increasing tourist } \\
\text { traffic. }\end{array}$ & 4,33 & ,687 & 4 & 4 \\
\hline Hotel profit & & & & \\
\hline
\end{tabular}


Analyzing the attitudes of managers on the representation of hotel tourism in the conditions of the modern globalization process

\begin{tabular}{|c|c|c|c|c|}
\hline $\begin{array}{l}\text { It is characteristic of your hotel to pay } \\
\text { special attention to improving the } \\
\text { complete offer, reducing operating } \\
\text { costs, raising the level of overall } \\
\text { quality in order to achieve the highest } \\
\text { possible profit. }\end{array}$ & 4,77 & ,527 & 5 & 5 \\
\hline $\begin{array}{l}\text { In order to achieve the success of the } \\
\text { hotel business, it is necessary to } \\
\text { periodically compare financial } \\
\text { indicators with other competitors in } \\
\text { the hotel industry. }\end{array}$ & 4,26 & ,819 & 5 & 4 \\
\hline $\begin{array}{l}\text { Continuous training of hotel staff and } \\
\text { introduction of innovations has a } \\
\text { positive effect on profit. }\end{array}$ & 4,56 & ,796 & 5 & 5 \\
\hline $\begin{array}{l}\text { The amount of hotel profits is a key } \\
\text { factor in investing in the concept of } \\
\text { hotel business excellence. }\end{array}$ & 4,49 & ,856 & 5 & 5 \\
\hline
\end{tabular}

Source: author's creation

When it comes to the market position of the hotel, managers believe that the most important claims that "With the development of tourism and its structure, the hotel increasingly emphasizes the strategy of differentiating the package according to relevant market segments" and "Improving service quality and monitoring new trends in the tourism market is a prerequisite for gaining a good competitive position in the market "with an average score of 4.63. As part of the assessment of the importance of tourist traffic, the statements "Cooperation with tourist agencies is an important factor in hotel tourist traffic" 4.67 and "Flexible reservation policy is an important factor in attendance" 4.60 stand out significantly. Furthermore, when assessing the importance of hotel profits, the highest average score was given to the statements "Your hotel is characterized by strong attention to improving the complete offer, reducing operating costs, raising the overall quality to maximize profits" and "Continuous training of hotel staff and innovation positively affects profit "4.56. We can conclude that the most important thing for hotel managers is to improve the complete offer and reduce costs, in order to achieve the highest possible profit. Observing the previously mentioned parameters, market position, tourist turnover and hotel profit, the managers collectively for all statements, rated the highest average rating of hotel profit 4.7 , then market position 4.52 , then tourist turnover 4.47 , which implies the conclusion, that, nevertheless, the profit of hotels from their point of view is the most important in the process of improving the hotel business.

\section{CONCLUSION}

The most significant conclusions in the paper can be presented as follows: 
- Evaluation of the importance of the variable "Tourist satisfaction" from the aspect of managers, showed that hotel managers rated the highest "Friendliness and kindness of hotel staff" 4.93 , followed by three variables with an average rating of 4.86, namely: "Reception at reception "," Execution of promises on time "and" Prompt hotel service ". Furthermore, the two variables have the same average score of 4.79, namely "Location and transport accessibility of the hotel" and "Security in conducting transactions with hotel staff".

- The highest degree of agreement of hotel managers with the proposed statements, when it comes to assessing the importance of the dependent variable "Implementation of various hotel services", is evident in accommodation services, where the average score is 4.86 , then gastronomy 4.79 , congress tourism 4.47 , cultural content (local attractions and events) 4.19 and wellness services 4.07. The average score below four had the variables contents for children and sports contents 3.72. Therefore, in this sample, the surveyed managers believe that in the process of improving the hotel business, accommodation and gastronomic services are extremely important, which also largely determine the dependent variable implementation of various hotel services.

- When it comes to the market position of the hotel, managers believe that the most important claims are that "With the development of tourism and its structure, the hotel increasingly emphasizes the strategy of differentiating the package according to relevant market segments" and "Improving service quality and monitoring new trends in the tourism market is a basic prerequisite in gaining a good competitive position in the market "with an average score of 4.63 .

- As part of the assessment of the importance of tourist traffic, the statements "Cooperation with tourist agencies is an important factor in hotel tourist traffic" 4.67 and "Flexible reservation policy is an important factor in attendance" 4.60.

- In assessing the importance of hotel profits, the highest average score was given to the statements "Your hotel is characterized by strong attention to improving the complete offer, reducing operating costs, raising the overall quality to maximize profits" and "Continuous training of hotel staff and innovation positively affects profit "4.56. We can conclude that the most important thing for hotel managers is to improve the complete offer and reduce costs, in order to achieve the highest possible profit.

- If we look at all the above variables together, market position, tourist traffic and hotel profit, managers collectively for all statements, the highest average rating of hotel profit 4.7, then market position 4.52, then tourist traffic 4.47, which implies the conclusion that, nevertheless, the profit of hotels from their point of view is the most important in the process of improving the hotel business.

It is evident that hoteliers in $\mathrm{BiH}$ have taken the path of quality, but however, they are not yet doing so systemically. The introduction of international standards, application and business according to the concept of business excellence, the use of best practice experiences, monitoring of modern trends, is generally reduced only to the initiatives of individuals. However, this is not enough, since hoteliers today are required to excel in every segment of the business, in all performances, which requires the adoption of new forms and strategies for managing the entire business. It is notorious that Bosnian hoteliers have great prospects, but first and foremost they have to solve many 
Analyzing the attitudes of managers on the representation of hotel tourism in the conditions of the modern globalization process

problems and weaknesses, in order to improve all the performance of business excellence. By using a self-assessment of a company's own business excellence based on its performance, very good indicators of the situation can be reached, as well as conclusions about the areas of business that need to be improved.

It is indisputable that no world-famous and recognized tourist destination, ie country, has achieved its development and affirmation without the help and supervision of the state itself. Tourism plans, development strategies, tourism investments and their protection, control, supervision of activities, legal framework, etc. are just some of the factors where the role of the state is not only necessary but also necessary. Only the active role of the state can recognize, develop and preserve the tourist potentials of the country, and place it as attractive and desirable, and thus lead to an influx of tourists, ie. their consumption which is the main economic factor of tourism.

In order to achieve sustainable and long-term growth, hotel companies must develop a deep understanding of the type of guests they want to attract, and then offer an experience that is tailored to a specific group of guests. Education of management and other employees is an important element in providing quality products and at the same time an element on which progress is being made in BiH. Namely, this year Bosnia and Herzegovina was at the prestigious fair of hotel and gastronomy in Lyon, where prestigious culinary competitions were held. Our representatives had the opportunity to go through education, but also to get acquainted with new trends. Given that trends and technology in the hotel industry are changing very quickly, it is necessary to constantly educate employees, which of course requires the allocation of appropriate financial resources. Despite its internal potential, the tourism sector in $\mathrm{BiH}$ is relatively small as it directly supports 32,458 jobs in the country. Hotel facilities in $\mathrm{BiH}$ generally meet the needs of mass tourism, and the unsatisfactory level of service quality is a consequence of the lack of standards in the design, construction and equipment of facilities. The quality of hotel services provided also depends on the maintenance of the facilities themselves, the level of comfort as well as the motivation and expertise of the staff. Namely, guests can forgive the lower level of hotel equipment, but they cannot forgive the messiness of the facility and the rudeness of the employees. If we keep in mind that tourism in the $\mathrm{FBiH}$ makes up between 55 and $60 \%$ of the total tourism in $\mathrm{BiH}$, then it can be estimated that the tourism industry generates about 270 million. dollars of GDP and about 15,000 jobs, and that the tourism economy creates about \$ 900 million of GDP and about 55,000 jobs. Given that these are estimates and that tourism has a high degree of gray economy, these indicators may increase by 35 to $40 \%$.

Limitation in the research: Data on hotel tourism in $\mathrm{BiH}$ are mainly compiled by the Agency for Statistics of $\mathrm{BiH}$, entity institutes and the Central Bank of $\mathrm{BiH}$. There are significant delays in processing information on tourist arrivals and departures (unique information does not really exist in $\mathrm{BiH}$ ), and immigration patterns (eg entry tickets) are not applied at all. Also, there is no information related to the consumption of inbound and outbound tourism or domestic tourist consumption, which is otherwise a prerequisite to see the trends of tourism in the country. It could be said that the statistics of tourism in general, and thus of hotel tourism in $\mathrm{BiH}$, is at the most basic level of presentation. However, another additional aggravating circumstance that occurs in the hotel business in $\mathrm{BiH}$ is the registration of guests, who are currently "the 
good will of hoteliers and catering workers." The non-registration of guests significantly reduces the share of tourism in GDP, which shows the negative attitude of statistics towards tourism, and in that sense we should work on changing the registration. Failure to report guests harms society as a whole and the state because they only benefit individuals, while society and the state do harm. The number of tourists is especially important for foreign investors, for whom official statistical indicators are not a guarantee of return and return on investment. From that money, the promotion of tourist potentials could be financed, because it is intended for local and entity tourist communities, which are now not able to finance BiH's marketing appearance on the European and world market.

\section{REFERENCE}

1. Čačić, K., Pavlović, D., Kvalitet kao osnova tržišnog uspeha hotelskog preduzeća, Beograd, 2011.

2. Enz, Cathy A., Hospitality Strategic Management: Concepts and Cases. 2nd Ed. New Jersy: John Wiley \& Sons, Inc., 2010.

3. Enz, K.A., Key Issuses of Concern in The Lodging Industry: What Worries Managers. Cornell University, Ithaca: TheCenter for Hospitality Research, 2009.

4. Kandampully, Jay, A., Services management: the new paradigm in hospitality, Pearson Education, Inc., Upper Saddle River, New Jersey, 2007.

5. Milardović, A., Poraz Europe, PanLiber, Osijek-Zagreb-Split, 1998.

6. Moutinho, L., Strateškimenadžmentuturizmu, Masmedia, Zagreb, 2005.

7. Njavro, Đ., Gospodarstvo, socijalna politika i globalizacija, Mate, Zagreb, 1999.

8. Nikolić, M., Menadžer i menadžment proces u hotelskoj industriji - savremeni pristup, Časopis Departmana za geografiju, turizam i hotelijerstvo, Turizam 6, 2002.

9. Perkov, D., Kvaliteta hotelske usluge je odraz organizacijske kulture, Zbornik radova "Hotellink", Beograd, 2005.

10. Sekulić,D.,Mandarić,M.,

Kvalitetuslugakaodeterminantasatisfakcijepotrošačauhotelijerstvu, Časopis Marketing, broj 44/3, 2013.

11. Sekulović, N., Kvalitet usluga i satisfakcija potrošača u turizmu, Beograd, 2009.

12. Vrtiprah, V., Sladoljev, J., Utjcaj zadovoljstva zaposlenika na kvalitetu proizvoda i usluga u hotelskom poduzeću, EKON. MISAOPRAKSADBK. GODXXI., 2012. BR. 1.

13. Turek, F., Globalizacija i globalna sigurnost, Hrvatska udruga za međunarodne studije, Varaždin, 1999.

14. Walker, J. R., Introduction to Hospitality, 5th Ed.: Person, Prentice Hall, New Jersey, 2009.

15. Žilić, I., Poslovna izvrsnost u visokokategoriziranim hotelima u Hrvatskoj, Šibenik, 2012.

16. Žilić, I., Utjecaj strategija poslovne izvrsnosti na performanse hotela u Republici Hrvatskoj, doktorska disertacija, Ekonomski fakultet, Split, 2011.

17. Softver SPSS24.0 
Analyzing the attitudes of managers on the representation of hotel tourism in the conditions of the modern globalization process

Web sites:

18. http://e-lib.efst.hr/2011/2092034.pdf (pristupljeno: Januar, 2016.)

19. http://web.efzg.hr/dok/TUR/avlahov/01_3A_struktura\%20hotelske\%20industrije.pd f (pristupljeno: Mart, 2016.)

20. http://www.academius.edu.rs/www.fimek.edu.rs/images/pdffajlovi/naucnirad/casopi s/arhiva/2011-ekonomija-br-4.pdf (pristupljeno: Decembar, 2016.)

21. http://unvi.edu.ba/Files/zbornici/turizam_u_funkciji_lokalnog_razvoja.pdf (pristupljeno: Novembar, 2016.)

22. https://bib.irb.hr/datoteka/472575.Samardzija_J-rad.pdf (pristupljeno: Maj, 2016.)

23. http://unvi.edu.ba/Files/zbornici/turizam_u_funkciji_lokalnog_razvoja.pdf (pristupljeno: Mart, 2016.)

24. http://www.fzs.ba/saopstenja.htm (pristupljeno: Maj, 2016.)

25. http://www.bhas.ba/saopstenja/2018/TUR_01_2018_01_0_BS.pdf

26. http://en.wikipedia.org/wiki/TripAdvisor (pristupljeno: Mart, 2016.)

27. http://www.ekapija.com/website/bih/page/738644/Hotel-Bristol-u-Sarajevu-dobiocertifikat-izvrsnosti-turisti\%C4\%8Dkog-portala-TripAdvisor (pristupljeno: April, 2016.)

28. http://unvi.edu.ba/Files/zbornici/turizam_u_funkciji_lokalnog_razvoja.pdf (pristupljeno: Novembar, 2016.)

29. https://bib.irb.hr/datoteka/472575.Samardzija_J-rad.pdf (pristupljeno: Maj, 2016.)

\section{REZIME}

Globalizacijski procesi sve više zahvataju i segmente turističkog tržišta, gdje se posebno ističe hotelijerstvo. Funkcionisanje turističkog tržišta u uslovima globalizacije zahtijeva izgrađenost međunarodne poslovne infrastrukture, koju predstavljaju brojne međunarodne institucije i sporazumi. Pravilno formirana međunarodna infrastruktura osigurava povoljnu klimu za globalizaciju, sveukupnom kontrolom i uviđanjem ekonomskog, finansijskog i političkog aspekta poslovanja. Razvoj turizma odnosno hotelijerstva u Bosni i Hercegovini tek je u početnoj fazi ali napredak ipak postoji. Imajući to u vidu, autorice su u radu prezentirale rezultate istraživanja I ispitivanja stavova menadžera o važnosti zadovoljstva turista, implementiranja različitih hotelskih usluga i pokazatelja uspješnosti hotelskih preduzeća u BiH. Autorice su došle do zaključka da su hotelijeri u BiH krenuli putem kvaliteta, ali međutim, to još ne čine sistemski. Notorno je, da bosanskohercegovački hotelijeri imaju veliku perspektivu, ali prvenstveno moraju riješiti brojne probleme i slabosti, kako bi unaprijedili sve performanse poslovne izvrsnosti. Korištenjem samoprocjene poslovne izvrsnosti vlastitog poduzeća na temelju njenih performansi, može doći do vrlo dobrih pokazatelja stanja, kao i zaključaka o područjima poslovanja koje je potrebno unaprijediti 